\title{
BEYOND RESOLUTION 2347 (2017): THE SEARCH FOR PROTECTION OF CULTURAL HERITAGE FROM ARMED NON-STATE GROUPS
}

\author{
Giulia Baj* \\ Università di Milano-Bicocca, Italy \\ g.baj1@campus.unimib.it
}

Received: 27 February 2020 | Last Revised: 3 November 2020 | Accepted: 22 February 2021

\begin{abstract}
One expression of cultural rights is the right to enjoy cultural heritage. However, the latter is not efficiently protected in situations of armed conflict. In many cases, armed non-State groups (ANSGs) have destroyed or looted cultural heritage items. The United Nations Security Council has intervened with Resolution 2347 (2017), welcomed by many as a milestone in the international protection of cultural heritage in conflict situations. However, this Resolution presents several limitations. The protection of cultural heritage from destruction and exploitation does not appear as the main focus, but rather as a means to fight terrorist groups. The attacks against cultural heritage are considered "war crimes", but only "under certain circumstances". The Resolution encourages States "that have not yet done so to consider ratifying" treaties on the issue in question; however, these instruments are treaties drafted and ratified by States. Problems of compliance by non-State actors, as ANSGs, arise. Hence, the capacity of the Resolution to effectively protect cultural heritage in conflicts involving ANSGs is debated. This paper analyses the text of Resolution 2347 (2017), resorting to traditional means of interpretation to highlight its limitations, and considers how a general sense of the necessity to protect cultural heritage from attacks committed by ANSGs has emerged, as demonstrated by the International Criminal Court's Al Mahdi case. The paper then considers other ways to guarantee the protection of cultural heritage from ANSGs. A proposal for stronger protection
\end{abstract}

Giulia Baj is a PhD candidate in Public, European and International Law at the University of Milano-Bicocca, Italy. She holds a Master's Degree in Law cum laude from the University of Pavia, Italy. Before graduating, she was a visiting student at the Columbia University of New York (Barnard College). 
of cultural heritage by States through both international humanitarian law (IHL) and international human rights law (IHRL) is presented. In particular, the connection between the protection of cultural heritage, the guarantee of cultural rights and other human rights is presented, resorting to instruments of doctrine and analyzing instruments of practice. Finally, the case for the stronger international cooperation for the protection of cultural heritage is made; problems of compliance by ANSGs may persist, but the systematic destruction of cultural heritage items can be considered a violation of cultural rights, thus requiring the cooperation of all international stakeholders.

Keywords: Cultural Heritage, Cultural Rights, International Human Rights Law, International Humanitarian Law.

\section{INTRODUCTION}

This paper analyzes the most significant aspects of UN Security Council Resolution 2347 (2017) (hereinafter, the Resolution). The Resolution deplores and condemns the unlawful destruction of cultural heritage. Its potential to provide effective protection, however, is impaired by some elements of the Resolution itself. In fact, the destruction of cultural heritage is not condemned because of its intrinsic disvalue, but rather as part of wider, unlawful plans; in particular, unlawful plans of terrorist groups. The potential to be a general condemnation of the acts of destruction of cultural heritage is diminished by the use of generic terms and the too frequent reference to specific terrorist groups, such as Da'esh and Al-Qaida. In this sense, it has to be noted that "terrorist groups" are just one of the several subcategories of armed nonState groups (hereinafter, ANSGs). Indeed, the term is used to refer to such a vast and heterogeneous group of entities that it is not possible to provide an accurate definition. ${ }^{.}$Some ANSGs have legal personality (albeit limited) such as insurgents and belligerents during an armed conflict; ${ }^{2}$ others do not. Some of

See, e.g., Wendy Pearlman and Kathleen Gallagher Cunningham, "Non-state Actors, Fragmentation, and Conflict Processes," Journal of Conflict Resolution 56, no. 1 (February 2012): 3-15, https://doi.org/10.1177/0022002711429669; Ulrich Schneckener, "Spoilers or Governance Actors?: Engaging Armed Non-State Groups in Areas of Limited Statehood" (SFB Governance working paper series, 21, 2009). https://www.sfb-governance.de/publikationen/ sfb-70o-working_papers/wp21/index.html; Margaret S Busé, "Non-State Actors and Their Significance," Journal of Conventional Weapons Destruction 5, no. 3 (2001).

2 See, e.g., Katharine Fortin, "The Law on Belligerency and Insurgency, and International Legal Personality," in The Accountability of Armed Groups under Human Rights Law (Oxford University Press), accessed September 21, 2020, https://oxford.universitypressscholarship.com/view/10.1093/oso/9780198808381.001.0001/oso-9780198808381chapter-4. 
them are bound by certain rules of international law, in particular international humanitarian law (hereinafter IHL), 3 others are not. More doubts have been expressed regarding the possibility to bind ANSGs to respect other branches of international law, including international human rights law (hereinafter, IHRL). Even the UN practice has been unclear on the topic, referring to conduct against human rights committed by ANSGs as "violations", but also as "abuses". 4 Despite this unclarity regarding both the identification of ANSGs and their obligations under international law, all ANSGs, during a conflict, can attack cultural heritage - and at times have done so.

The Resolution encourages States to adopt measures to reinforce international cooperation to protect cultural heritage; nonetheless, claims of state sovereignty were made even during the meeting in which the Resolution was voted upon. Thus, the Resolution lacks clarity. The protection of cultural heritage is strictly connected to the effective enjoyment not only of cultural rights, but also of other rights and freedoms. Therefore, the integration of IHL with IHRL should be pursued, to enhance the international cooperation among States aimed at safeguarding cultural heritage.

First, the Resolution is analyzed, resorting to the means of interpretation of UN Security Council resolutions, taking into consideration the guidelines provided by the International Court of Justice in its Namibia Advisory Opinion ${ }^{5}$ and the doctrine on the topic. ${ }^{6}$ Hence, the interpretation takes into account the

\footnotetext{
International Committee of the Red Cross, "Geneva Conventions on the Law of War," August 12, 1949, 75 No. 973, United Nations Treaty Series; "Protocol Additional to the Geneva Conventions of 12 August 1949 and Relating to the Protection of Victims of Non-International Armed Conflicts (Protocol II)," June 8, 1977, vol. 1125 (p. 6og), United Nations Treaty Series, https://treaties.un.org/doc/Publication/UNTS/Volume\%201125/v1125.pdf. In particular, Common Article 3 to the Geneva Conventions regards "armed conflicts not of an international character", whereas Article 1 of the Additional Protocol II, more explicitly, regards armed conflicts which take place in the territory of a High Contracting Party between its armed forces and dissident armed forces or other organized armed groups which, under responsible command, exercise such control over a part of its territory as to enable them to carry out sustained and concerted military operations and to implement this Protocol", and "shall not apply to situations of internal disturbances and tensions, such as riots, isolated and sporadic acts of violence and other acts of a similar nature, as not being armed conflicts".

4 In this regard, see Aristotle Constantinides, "Human Rights Obligations and Accountability of Armed Opposition Groups: The Practice of the UN Security Council," Human Rights \& International Legal Discourse 4, no. 1 (2010): 89-110.

5 Legal Consequences for States of the Continued Presence of South Africa in Namibia (South West Africa) notwithstanding Security Council Resolution 276 (1970), Advisory Opinion (International Court of Justice June 21, 1971).

6 Efthymios Papastavridis, "Interpretation of Security Council Resolutions under Chapter VII in the Aftermath of the Iraqi Crisis," International and Comparative Law Quarterly 56, no. 1 (January 2007): 83-118, https://doi.
} 
text the Resolution, the UN Charter provisions, and the previous resolutions recalled in it. The terms of the Resolution are interpreted in accordance with their ordinary meaning, considering the circumstances of its adoption, its object and purpose.

This analysis highlights both the strengths and weaknesses of the Resolution. In particular, the insufficient clarity regarding its binding or non-binding nature, and the restricted attention to one particular type of ANSGs (namely terrorist groups) are underlined. Then, the theoretical possibilities to bind ANSGs to respect cultural heritage are analyzed. As the framework for the effective protection of cultural heritage in current armed conflicts results is unclear and chaotic, and ultimately insufficient in practice, the case is made for the strengthening of international cooperation based not only on the provisions of the Resolution, but also on the rules of IHRL.

\section{RESOLUTION 2347 (2017) AND THE PROTECTION OF CULTURAL HERITAGE}

\subsection{Resolution 2347 (2017): Strengths}

The Resolution has been welcomed as a milestone in the protection of cultural heritage in case of armed conflict. The Resolution deals with one case of threat to international peace and security, whose removal constitutes one of the purposes of the United Nations (UN). ${ }^{7}$ In fact, the fourth preambular paragraph of the Resolution reaffirms "that terrorism in all forms and manifestations constitutes one of the most serious threats to international peace and security and that any acts of terrorism are criminal and unjustifiable regardless of their motivations, whenever and by whomsoever committed". ${ }^{8}$ The following paragraph emphasizes:

"the unlawful destruction of cultural heritage, and the looting and smuggling of cultural property in the event of armed conflicts, notably by terrorist

org/10.1093/iclq/lei151; Michael C. Wood, "Interpretation of Security Council Resolutions," Max Planck Yearbook of United Nations Law 2, (1998): 73-96.

Article 1, "Charter of the United Nations," signed on June 26, 1945, https://treaties.un.org/doc/Publication/UNTS/ No\%2oVolume/Part/un_charter.pdf.

8 Preamble, United Nations Security Council (hereinafter UNSC), Res. 2347, U.N. Doc.S/RES/2347 (March 24, 2017). 
groups, and the attempt to deny historical roots and cultural diversity in this context can fuel and exacerbate conflict and hamper post-conflict national reconciliation, thereby undermining the security, stability, governance, social, economic and cultural development of affected States".9

The Resolution highlights how a threat to international peace and security can include also attacks on cultural heritage. However, no explicit reference to Chapter VII of the UN Charter is made; this unclarity leaves doubts regarding the binding or non-binding nature of the Resolution.

The looting and smuggling of cultural heritage as a means to illicitly finance terroristic activities is stressed. The Resolution highlights how the destruction of items of cultural heritage can threaten cultural diversity, exacerbate conflict and impede its end. All this considered, the Resolution declares that these attacks to cultural heritage may, under certain circumstances, constitute war crimes. ${ }^{10}$ In the light of such considerations, a series of measures is addressed to Member States of the UN, in order to develop cooperation among States, international organizations and agencies. In fact, the Resolution

"requests Member States to take appropriate steps to prevent and counter the illicit trade and trafficking in cultural property and other items of archaeological, historical, cultural, rare scientific, and religious importance originating from a context of armed conflict, notably from terrorist groups, including by prohibiting cross-border trade in such illicit items".

It also "urges Member States to introduce effective national measures at the legislative and operational levels"12 and "to develop, including, upon request, with the assistance of UNODC, ${ }^{13}$ in cooperation with $\mathrm{UNESCO}^{14}$ and INTERPOL ${ }^{15}$ as appropriate, broad law enforcement and judicial cooperation

\footnotetext{
Preamble, UNSC, Res. 2347, U.N. Doc.S/RES/2347 (March 24, 2017).

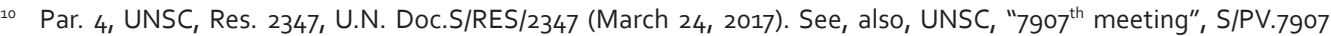
(March 24, 2017), in which it is stated: "what we are witnessing is, in many cases, war crimes. This is not just wanton pillaging and vandalism; this is a matter of international peace and security".

11 Par. 8, UNSC, Res. 2347, U.N. Doc.S/RES/2347 (March 24, 2017).

12 Par. 9, UNSC, Res. 2347, U.N. Doc.S/RES/2347 (March 24, 2017).

13 Acronym, United Nations Office on Drugs and Crime.

14 Acronym, United Nations Educational, Scientific and Cultural Organization.

15 Contraction, International Police; full name International Criminal Police Organization.
} 
in preventing and countering all forms and aspects of trafficking in cultural property and related offences".16 Private stakeholders should be involved as well; in fact, the Security Council "calls upon Member States (...) to consider (...) engaging museums, relevant business associations and antiquities market participants ${ }^{{ }_{17}}$ in the adoption of measures necessary to prevent and counter the trafficking of cultural properties.

The involvement of different stakeholders other than States and the request of international cooperation have been positively welcomed; in fact, as affirmed by one of the members of the Security Council, the "universalization of the international framework to protect cultural heritage is crucial". ${ }^{8}$ Despite the positive elements contained in the Resolution, and the follow-up actions undertaken by States and stakeholders, ${ }^{19}$ in the years following the adoption of the Resolution there has not been a dramatic decrease in the international trafficking of cultural heritage items. ${ }^{20}$ All things considered, the Resolution has not yet had the desired results. Hence, it is useful to continue the analysis of its text, in search of possible shortcomings.

\subsection{Resolution 2347 (2017): Weaknesses}

The Resolution has been widely welcomed as an important step in the protection of cultural heritage in case of armed conflicts. However, this aspect does not clearly appear by reading the whole text of the Resolution. The destruction of cultural heritage in the event of armed conflict is condemned several times; however, the Security Council does not focus on the destruction of cultural heritage per se. Rather, it appears that the

16 Par. 11, UNSC, Res. 2347, U.N. Doc.S/RES/2347 (March 24, 2017).

17 Par. 17 (g), UNSC, Res. 2347, U.N. Doc.S/RES/2347 (March 24, 2017).

18 UNSC, "7907 meeting", S/PV.7907 (March 24, 2017).

19 See, e.g., INTERPOL, "Protecting Cultural Heritage through Interagency Cooperation. WIESBADEN, Germany - International Experts on the Illicit Trade of Cultural Property Have Met to Boost Interagency Cooperation Both at the National and International Level," September 23, 2019, https://www.interpol.int/News-and-Events/ News/2019/Protecting-cultural-heritage-through-interagency-cooperation.

20 INTERPOL, "The Issues - Cultural Property," accessed October 20, 2020, https://www.interpol.int/Crimes/Culturalheritage-crime/The-issues-cultural-property. It has to be noted, however, that since it is an illicit trade, it is not possible to know the exact number of items involved and the monetary value of the trade. 
Resolution, through the declaration of the unlawfulness of the destruction of cultural heritage, condemns the acts of ANSGs primarily, terrorist groups in particular. In fact, the Security Council notes "with grave concern the involvement of non-state actors, notably terrorist groups, in the destruction of cultural heritage". ${ }^{21}$ It has to be noted that the Resolution refers to "non-state actors", which is a general term used to refer to entities that are not States but are relevant in the international scenario. ${ }^{22}$ However, interpreting the provision as a whole, it is clear that it refers to ANSGs, as it discusses terrorist groups and the destruction of cultural heritage during armed conflicts. Once clarified that the Resolution discusses, in particular, the problem of ANSGs, the interpretation of this term in accordance with its ordinary meaning remains difficult. In fact, the term ANSGs refers to such a wide and heterogeneous list of entities that there is not a precise and commonly accepted definition. To show the difficulty in defining these entities, it is sufficient to recall one of the many attempts: ANSGs are "organizations with less than full international recognition as a government, who employ a military strategy".23

Thus, the term and its synonyms have been used to refer to a variety of actors, from insurgents, to militias, rebel groups, national liberation movements, warlords. ${ }^{24}$ Terrorist groups, multiple times recalled in the Resolution, are just one of the many sub-categories constituting ANSGs; in particular, these are the groups that resort to violent means to spread terror in such a pervasive way that their means define their nature. ${ }^{25}$ In

\footnotetext{
21 Preamble, UNSC, Res. 2347, U.N. Doc.S/RES/2347 (March 24, 2017).

22 See International Law Association, "Johannesburg Conference on Non State Actors" (Report of Conferences, International Law Association, 2016); Graham Evans and Jeffrey Newnham, The Penguin Dictionary of International Relations (Penguin Group USA, 1998); Florence Gaub, "State Vacuums and Non-State Actors in the Middle East and North Africa," in The Frailty of Authority Borders, Non-State Actors and Power Vacuums in a Changing Middle East, ed. Lorenzo Kamel (Roma: Edizioni Nuova cultura, 2017), 51-66.

23 Busé, "Non-State Actors and Their Significance."

${ }^{24}$ See, example, Annyssa Bellal, "What Are 'Armed Non-State Actors'? A Legal and Semantic Approach," in International Humanitarian Law and Non-State Actors, ed. Ezequiel Heffes, Marcos D. Kotlik, and Manuel J. Ventura (The Hague: T.M.C. Asser Press, 2020), 21-46, https://doi.org/10.1007/978-94-6265-339-9_2; Richard H. Shultz, Douglas Farah, and Itamara V. Lochard, "Armed Groups: A Tier-One Security Priority" (INSS Occasional Paper, USAF Institute for National Security Studies, 2004); Brian McQuinn and Fabio Oliva, "Preliminary Scoping Report - Analyzing and Engaging Non-State Armed Groups in the Field" (United Nations System Staff College, n.d.).

25 See Shultz, Farah, and Lochard, "Armed Groups."
} 
this sense, it is useful to recall the IHL definition of acts of terrorism: "acts or threats of violence the primary purpose of which is to spread terror among the civilian population". ${ }^{26}$ It has to be noted, however, that also other types of ANSGs can resort - and have resorted - to terroristic means; ${ }^{27}$ therefore, the identification of a terrorist group is particularly complex. However, the Resolution just mentions other "non-state actors" involved in armed conflicts ${ }^{28}$ and then focuses on terrorist groups only. Doing so, the Resolution does not duly consider several other types of ANSGs, which are equally involved in armed conflicts and the destruction and exploitation of cultural heritage.

Not only, the Resolution does not refer to terrorist groups in general, but Al-Qaida and Da'esh in particular. ${ }^{29}$ Like the majority of UN Security Council resolutions, the Resolution is not self-contained, and in fact, it refers to several previous resolutions; thus, they have to be taken into consideration during interpretation. ${ }^{30}$ The Security Council "encourages Member States to propose listings of ISIL, Al-Qaida and associated individuals, groups, undertakings and entities involved in the illicit trade in cultural property to be considered by the 1267/1989/2253 ISIL (Da'esh) and Al-Qaida Sanctions Committee". ${ }^{31}$ These resolutions establish a sanction regime based on lists

26 "Protocol Additional to the Geneva Conventions of 12 August 1949 and Relating to the Protection of Victims of Non-International Armed Conflicts (Protocol II)."

27 See Schneckener, "Spoilers or Governance Actors?"

28 Preamble, UNSC, Res. 2347, U.N. Doc.S/RES/2347 (March 24, 2017).

29 The Security Council noted "with concern that the Islamic State in Iraq and the Levant (ISIL, also known as Da'esh), Al-Qaida and associated individuals, groups, undertakings and entities are generating income from engaging directly or indirectly in the illegal excavation and in the looting and smuggling of cultural property", recalled its condemnation "of any engagement in direct or indirect trade involving ISIL, Al-Nusra Front (ANF) and all other individuals, groups, undertakings and entities associated with Al-Qaida" and condemned in particular the activities of looting and pillage "committed by ISIL, Al-Qaida and associated individuals, groups, undertakings and entities". The strongest reference to these particular situations can be found in paragraph 8 , which states that "in particular items illegally removed from Iraq since 6 August 1990 and from Syria since 15 March 2011, and recalls in this regard that States shall ensure that no funds, other financial assets or other economic resources are made available, directly or indirectly, by their nationals or persons within their territory for the benefit of ISIL and individuals, groups, entities or undertakings associated with ISIL or Al-Qaida in accordance with relevant Resolutions". UNSC, Res. 2347, U.N. Doc.S/RES/2347 (March 24, 2017).

30 See Legal Consequences for States of the Continued Presence of South Africa in Namibia (South West Africa) notwithstanding Security Council Resolution 276 (1970), Advisory Opinion, ICJ Reports 1971; Wood, "Interpretation of Security Council Resolutions."

${ }^{31}$ Par. 10, UNSC, Res. 2347, U.N. Doc.S/RES/2347 (March 24, 2017). 
of individuals and entities associated with these two ANSGs; consequently, the simple unlawful trafficking in cultural heritage is not enough to be listed, as the subjects involved in illicit trade in cultural property must also be associated with ISIL or Al-Qaida. It appears, again, that the protection of cultural heritage is functional to the wider fight against terrorism, in particular against a few specific terrorist groups.

The link between attacks on cultural heritage in armed conflicts and these groups is thus twofold. On a practical level, the trafficking of cultural heritage items provides illicit financing for their activities; on a more theoretical level, their destruction can demoralize a people, constituting an advantage during a conflict. However, after reading the Resolution, taking into consideration also the previous resolutions mentioned in its Preamble, ${ }^{32}$ its main topic appears to be the fight against terrorism, which "constitutes one of the most serious threats to international peace and security".33 The destruction of cultural heritage is condemned because its smuggling and looting is an illicit way to finance terrorism; the fact that it can consist of a violation of human rights in itself is not duly highlighted. ${ }^{34}$

The Resolution mostly consists of generic provisions. Cooperation among UN Member States and the relevant UN entities aimed at preventing the illicit trafficking of cultural heritage is encouraged; however, States are generally asked to "take appropriate steps", "take preventive measures", and "introduce effective national measures" to safeguard their cultural heritage. ${ }^{35}$ Out of 23 paragraphs, only paragraph 17 presents a list of specific concrete actions that should be undertaken, e.g., establishing national archives of cultural heritage and databases and contributing to the INTERPOL Database

\footnotetext{
32 The resolutions recalled are 1267 (1999), 1373 (2001), 1483 (2003), 1546 (2004), 2056 (2012), 2071 (2012), 2085 (2012), 2100 (2013), 2139 (2014), 2170 (2014), 2195 (2014), 2199 (2015), 2249 (2015), 2253 (2015) and 2322 (2016), as well as its Presidential Statement S/PRST/2012/26; Preamble, UNSC, Res. 2347, U.N. Doc.S/RES/2347 (March 24,2017 ). On the necessity to read and connect multiple resolutions in order to understand them, see Wood, "Interpretation of Security Council Resolutions."

33 Preamble, UNSC, Res. 2347, U.N. Doc.S/RES/2347 (March 24, 2017).

34 Kristin Hausler, "Cultural Heritage and the Security Council: Why Resolution 2347 Matters," QIL-Question of International Law. QIL, Zoom-In 48 (2018): 5-19.

35 Parr. 8, 9, UNSC, Res. 2347, U.N. Doc.S/RES/2347 (March 24, 2017).
} 
of Stolen Works of Art - while recalling, again, that the illegal trafficking of cultural property is caused "notably by terrorist groups" ${ }^{6}$

The majority of these measures are not binding. The Security Council "invites", "encourages", and "urges" in most of the paragraphs of the Resolution. Paragraph 19 of the Resolution presents the possibility to entrust to peacekeeping operations the protection of cultural heritage; even though enthusiastically acclaimed as a step forward in international protection of cultural heritage, this paragraph is quite limited. In fact, it

"affirms that the mandate of United Nations peacekeeping operations, when specifically mandated by the Security Council and in accordance with their rules of engagement, may encompass, as appropriate, assisting relevant authorities, upon their request, in the protection of cultural heritage from destruction" (emphasis added). ${ }^{37}$

Considering also how no reference is made to Chapter VII of the UN Charter, even though the Resolution states multiple times that it is dealing with a threat to international peace and security, the measures adopted appear neither particularly precise, nor explicitly binding.

The praised protection of cultural heritage appears weak and the Resolution unclear. Analyzing the meeting records as an interpretation tool,,$^{38}$ the purpose of providing stronger international protection to cultural heritage through international cooperation seems narrowed by claims to respect state sovereignty. During the meeting which led to the adoption of the Resolution, in fact, it was affirmed:

"the key role is to be played by each individual State in the protection of its own cultural heritage. Efforts to protect cultural heritage during armed conflict must respect the provisions of the Charter of the United Nations and be pursued strictly in line with international law. The importance of respecting a state's sovereignty is also key, as is respect for the principle of non-interference in the internal affairs of States". 39

36 Par. 17, UNSC, Res. 2347, U.N. Doc.S/RES/2347 (March 24, 2017).

37 Par. 19, UNSC, Res. 2347, U.N. Doc.S/RES/2347 (March 24, 2017).

38 See Papastavridis, "Interpretation of Security Council Resolutions."

39 UNSC, "7907 $7^{\text {th }}$ meeting", S/PV.7907 (March 24, 2017). 
The generalized claims to national sovereignty, ${ }^{40}$ typical of the current international scene, affects also cultural heritage. In fact, "a number of cultural heritage issues lie within the core of State sovereignty and refer to the defense of statehood in the global world against real and imagined threats to cultural State identity."41

\section{ANSGs AND SHORTCOMINGS IN CULTURAL HERITAGE PROTECTION IN ANSAs PERSPECTIVE}

\subsection{The Hague Convention, the Second Protocol of 1999 and their Deficiencies}

Resolution 2347 (2017) contains a series of provisions addressed to States in order to more effectively protect cultural heritage in case of armed conflicts. However, even these measures have severe shortcomings, related in particular to the nature of current conflicts. In fact, in 2018, 51 non-international armed conflicts took place, while the international ones were only 18;42 4 new non-international armed conflicts broke out. ${ }^{43}$ The diffusion of non-international armed conflict is significant also for another aspect; as these conflicts involve at least one dissident armed force or other organized armed groups, ANSGs are included in the majority of current conflicts. Their relevance in the protection of cultural heritage, therefore, must not be underestimated.

The Resolution "encourages the Member States that have not yet done so to consider ratifying the Convention for the Protection of Cultural

\footnotetext{
$4^{\circ}$ See Paul B. Richardson, "Sovereignty, the Hyperreal, and 'Taking Back Control,"' Annals of the American Association of Geographers 109, no. 6 (November 2, 2019): 1999-2015, https://doi.org/10.1080/24694452.2019.1587283; Macer Hall, "Boris Johnson Urges Brits to Vote Brexit to 'Take Back Control,'" Daily Express, June 20, 2016, https://www. express.co.uk/news/politics/681706/Boris-Johnson-vote-Brexit-take-back-control; Satur Ocampo, "Duterte's Odd Defense of Philippine Sovereignty," Bulatlat, April 22, 2018, https://www.bulatlat.com/2018/04/22/dutertes-odddefense-philippine-sovereignty/; Will Pavia, "Amazon Rainforest Belongs to Brasil Not Mankind, Bolsonaro Tells UN," The Times, September 25, 2019, https://www.thetimes.co.uk/article/amazon-rainforest-belongs-to-brazilnot-mankind-bolsonaro-tells-un-2j2f 55 l2j.

${ }^{41}$ Andrzej Jakubowski, "Resolution 2347: Mainstreaming the Protection of Cultural Heritage at the Global Level," Questions of International Law 48 (2018): 21-44.

42 Alessandro Mario Amoroso et al., "The War Report: Armed Conflicts in 2018" (A Paper, Geneva Academy of International Humanitarian Law and Human Rights, 2019).

43 Amoroso, "The War Report."
} 
Property in the Event of Armed Conflict of 14 May 1954 and its Protocols, as well as other relevant international conventions". ${ }^{44}$ This request presents critical issues, besides the scarce number of ratifications and accessions following the Resolution (in particular, the Second Protocol currently has only 82 State Parties). ${ }^{45}$ First, the Resolution encourages ratification of the Convention, which was adopted in 1954. This temporal element is significant, as the characteristics of warfare of that period are very different from the ones of modern conflicts. In the 1950s, wars were perceived as events between States only, thus of international nature. World War II was an event of recent history. ${ }^{6}$ The provisions of the Hague Convention, therefore, are principally meant to apply in times of international conflicts. ${ }^{47}$

Article 19 of the Hague Convention provides for the application of the Convention in case of armed conflicts not of an international character; ${ }^{4}$ however, no definition of this type of conflict is provided, leaving ample space for interpretation. ${ }^{49}$ It has been stated that "non-international

44 Par. 7, UNSC, Res. 2347, U.N. Doc.S/RES/2347 (March 24, 2017).

45 After the Resolution, 5 States have ratified and accessed the Hague Convention, bringing the number of State Parties to 133. 5 States have accessed and ratified the First Protocol as well, bringing the number of State Parties to 110, whereas 10 States have accessed and ratified the Second Protocol, which now has 82 State Parties. Lists available at unesco.org, last accessed October 27, 2019. Moreover, considering recent events, it is important to underline that neither Syria nor Iraq are Parties to the second Protocol, and Afghanistan's accession occurred in 2018. Despite the follow-up actions undertaken by international agencies and other stakeholders, States have not been equally receptive.

${ }^{46}$ Reference to the events occurred in the first part of the $19^{\text {th }}$ Century can be found already in the Preamble of the Hague Convention: "The High Contracting Parties, recognizing that cultural property has suffered grave damage during recent armed conflicts (...)". "Convention for the Protection of Cultural Property in the Event of Armed Conflict", signed on May 14, 1954, United Nations Treaty Series no. 249, 215, https://treaties.un.org/ Pages/showDetails.aspx?objid=0800000280145bac.

47 The priority given to international conflicts appears, e.g., in Article 18, "Application of the Convention", which states that: "1. Apart from the provisions which shall take effect in time of peace, the present Convention shall apply in the event of declared war or of any other armed conflict which may arise between two or more of the High Contracting Parties, even if the state of war is not recognized by, one or more of them. 2. The Convention shall also apply to all cases of partial or total occupation of the territory of a High Contracting Party, even if the said occupation meets with no armed resistance." Art. 18, "Convention for the Protection of Cultural Property in the Event of Armed Conflict", signed on May 14, 1954, United Nations Treaty Series no. $249,215$.

48 "In the event of an armed conflict not of an international character occurring within the territory of one of the High Contracting Parties, each party to the conflict shall be bound to apply, as, a minimum, the provisions of the present Convention which relate to respect for cultural property". Art. 19.1, "Convention for the Protection of Cultural Property in the Event of Armed Conflict", signed on May 14, 1954, United Nations Treaty Series no. 249, 215.

49 It has been noted that vagueness itself has been considered a characteristic of the Hague Convention, to the detriment of the efficacy of its provisions. See Eric A. Posner, "The International Protection of Cultural Property: Some Skeptical Observations," Chicago Journal of International Law 8, no. 1 (n.d.): 213-32. 
armed conflicts are distinct from international armed conflicts on the one hand (...) and internal disturbances and tensions on the other", $5^{\circ}$ thus implying a minimum threshold to be reached. The difference with internal tensions has been pinpointed also in commentaries on Common Article 3 (hereinafter $\mathrm{CA}_{3}$ ) to the Geneva Conventions, and confirmed in Article 1.2 of the Additional Protocol II to the Geneva Conventions (hereinafter APII); differences in the elements necessary to identify such conflicts can be found also in the principal instruments of IHL. However, the Commentary of the International Committee of the Red Cross (hereinafter ICRC) of 2016 on $\mathrm{CA}_{3}$ highlights how this Article and the APII have different material fields of application. Paragraph 394 of this Commentary, in fact, reads that "it is widely accepted that non-international armed conflicts in the sense of $\mathrm{CA}_{3}$ also comprise armed conflicts in which no State party is involved",51 whereas "Additional Protocol II does not apply to such conflicts". ${ }^{2}$ Given these unclarities and gaps, Article 19 of the Hague Convention cannot be considered as an effective safeguard of cultural heritage in case of noninternational armed conflicts, as its material field of application is unclear.

The Resolution, however, refers also to the Protocols to the Hague Conventions. The Second Protocol to the Hague Convention is particularly interesting, as it was opened to ratification in 1999, after the events occurred during the conflict in the former Yugoslavia, aiming to update the provisions of the Hague Convention to modern conflicts. ${ }^{33}$ However, in the Protocol of

50 Dieter Fleck, The Handbook of International Humanitarian Law (Oxford and New York: Oxford University Press, 2013).

${ }^{51}$ International Committee of the Red Cross (Hereinafter ICRC), "Convention (I) for the Amelioration of the Condition of the Wounded and Sick in Armed Forces in the Field, Geneva, 12 August 1949, Commentary of 2016. Article 3: Conflicts not of an international character," International Committee of the Red Cross, accessed August 22, 2020, https://ihl-databases.icrc.org/applic/ihl/ihl.nsf/Comment.xsp?action=openDocument\&documentld=59F6CD FA490736C1 $C_{1257} F_{7}$ Doo4BAoEC. Such position is confirmed also by the Statute of International Criminal Court, which considers armed conflicts not of an international nature those conflicts in which "there is protracted armed conflict between governmental authorities and organized armed groups or between such groups", Art. 8, "Rome Statute of the International Criminal Court", signed on July 17, 1998, United Nations Treaty Series, vol. 2187, No. 38544.

52 ICRC, "Convention (I) for the Amelioration of the Condition of the Wounded and Sick in Armed Forces in the Field, Geneva, 12 August 1949, Commentary of 2016. Article 3: Conflicts not of an international character," International Committee of the Red Cross, accessed August 22, 2020, https://ihl-databases.icrc.org/applic/ihl/ ihl.nsf/Comment.xsp?action=openDocument\&documentld=59F6CDFA490736C 1 C 1257F7Do04BAoEC.

53 See Art. 22 "Second Protocol the Hague Convention of 1954 for the Protection of Cultural Property in the Event of Armed Conflict", signed on March 26, 1999, United Nations Treaty Series no. 2253, 172, https://treaties.un.org/ Pages/showDetails.aspx?objid=0800000280076dd2. In particular, Art. 22.2 is identical to Art. 1.1 of the Additional 
1999, the unclarity regarding the wording "conflicts not of an international character" still persists. Article 22 of this instrument states that it "shall apply in the event of an armed conflict not of an international character, occurring within the territory of one of the Parties" and specifies that it "shall not apply to situations of internal disturbances and tensions, such as riots, isolated and sporadic acts of violence and other acts of a similar nature". Surely, this corresponds with APII; however, no definition of what does constitute a non-international armed conflict in given.

\subsection{ANSGs and Conventional Law: Ineffective Safeguard}

The Hague Convention and its Second Protocol are conventional instruments. They are binding on the State Parties; however, in the current scenario it is of particular importance to assess whether they are binding for ANSGs as well or not. Article 19 of the Hague Convention states that "each party to the conflict shall be bound to apply" ${ }^{4}$ the provisions of the Convention itself related to cultural property. Since "party" is written without the capital "P", it is suggested that it refers not only to States but also to the ANSGs taking part in the conflict, eventually binding the latter as well. 55 Also, the Second Protocol uses both the terms "party" and "Party". However, an interpretation in the light of the object and the purpose of the treaty ${ }^{56}$ leads to the application of the provisions of the Second Protocol to States and ANSGs. ${ }^{57}$

This expansion of the recipients of the Convention would ensure a stronger protection of cultural heritage; ANSGs, however, are often not

Protocol II to the Geneva Conventions, thus excluding situations of internal disturbances and tensions, isolated and sporadic acts of violence from the scope of application. The definition of internal conflict by exclusion of certain situations is, therefore, the same. The threshold to be reached to apply the Second Protocol, therefore, is the same required to apply the rules of IHL.

54 Article 19, "Convention for the Protection of Cultural Property in the Event of Armed Conflict," signed on May 14, 1954, United Nations Treaty Series no. 249, 215.

55 Patty Gerstenblith, "Beyond the 1954 Hague Convention," in Cultural Awareness in the Military: Developments and Implications for Future Humanitarian Cooperation (Springer, 2014), 83-99.

56 Art. 32(b), "Vienna Convention on the Law of Treaties", opened for signature May 23, 1969, United Nations Treaty Series no. 1155, https://treaties.un.org/doc/Treaties/1980/01/19800127\%2000-52\%20AM/Ch_XXIII_01.pdf

57 Jean-Marie Henckaerts, "The Protection of Cultural Property in Non-International Armed Conflicts," in Protecting Cultural Property in Armed Conflict, ed. Nout van Woudenberg and Liesbeth Lijnzaad, International Humanitarian Law Series, v. 29 (Leiden; Boston: Martinus Nijhoff Publishers, 2010), 81-93. 
keen to comply with the obligations of conventional provisions. Problems of compliance lie in the perceived injustice, for ANSGs, to be bound by conventional rules they had no part in the elaboration of, and to respect conventions ratified by the State they are fighting against. It has been noted, in fact, that "ANSAs [Armed Non-State Actors] perceive the international legal system as biased and privileging States". ${ }^{8}$

Different theories have been proposed to apply conventional instruments of international law to ANSGs. The two main theories which provide a legal basis are the so-called effective sovereignty argument and the domestic legislative jurisdiction argument. However, these theories are not generally accepted. It has been argued, in fact, that these arguments do not take into appropriate consideration the strong contrast between ANSGs and States, which consider themselves as opponents, and the qualitative difference between an ANSG and the sum of its members. The effective sovereignty argument claims that ANSGs are obliged to respect international obligations derived from conventional instruments ratified or accessed by the State they are fighting against, as a successor State would do. The domestic legislative jurisdiction argument claims that an international treaty, binding a State, is necessarily binding for its nationals as well. The criticisms regard the fact that the former takes for granted the fact that the ANSG claims to represent the State, which is not always the case; the latter does not consider that an ANSG might be comprised also by persons who are not nationals of the State the ANSG is fighting against. Given these considerations, the application to ANSGs of the conventional instruments which are binding for the State in which they are located is not generally accepted, and problems of compliance to the conventionally established rules persist.

All that considered, it appears that the ratification of the Hague Convention and its Protocols, encouraged in Resolution 2347 (2017), is

Ashley Jackson, "In Their Words: Perceptions of Armed Non-State Actors on Humanitarian Action," (Geneva: Geneva Call, May 2 https://www.genevacall.org/wp-content/uploads/dlm_uploads/2016/og/WHS_Report_2016_web. pdf.016), 
surely aimed at involving more strongly Member States of the UN in the protection of cultural heritage in the event of armed conflict, but is not probably sufficient. The protection offered by conventional instruments recalled in Resolution 2347 (2017) cannot currently be considered as an effective means to protect cultural heritage in any conflict. In particular, these have strong problems of compliance regarding their respect by the ANSGs. The involvement of States in the protection of cultural heritage from the attacks that may occur during armed conflicts is therefore necessary. It is the "primary responsibility of States to protect their cultural property" 59 and "failure to achieve that goal is the result not of a lack of existing international instruments, but rather of States' will to abide by their commitments and obligations", ${ }^{60}$ which include not only rules of IHL, but also of IHRL.

\section{PROTECTING CULTURAL HERITAGE THROUGH THE INTEGRATION OF IHL AND IHRL}

\subsection{The Link between Cultural Heritage and Cultural Rights}

It is true that Rule 38 of the customary IHL rules studied by the ICRC establishes that "[e]ach party to the conflict must respect cultural property. [...] Property of great importance to the cultural heritage of every people must not be the object of attack unless imperatively required by military necessity", ${ }^{61}$ thus binding both States and ANSGs. Despite these customary and conventional provisions, cultural heritage is still looted and destroyed. IHL rules alone cannot provide the most effective protection to cultural heritage in case of current armed conflicts. It is therefore suggested to supplement IHL with IHRL to afford a stronger protection, as the respect by States of IHRL has acquired, since the end of World War II, such a general recognition that some provisions of the Universal Declaration of

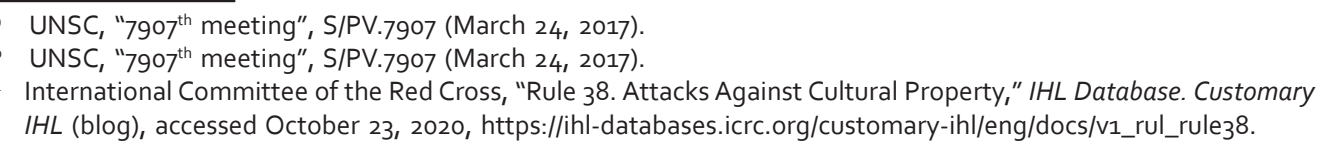


Human Rights, the milestone in the codification of human rights, are nowadays considered customary law. ${ }^{62}$

Cultural heritage is strongly linked to human rights, cultural rights in particular; indeed, it can be considered as a necessary means for their realization, as those include the right to enjoy and participate in cultural life. Moreover, cultural rights are key components for the fulfillment of other human rights; the protection of cultural heritage, therefore, is an important resource to guarantee their effective enjoyment.

Cultural heritage can be broadly defined as the corpus of material signs, proofs of the history and culture of a certain community, handed on by the past, whose value is so significant that it must be considered fundamental for the whole mankind. Tangible cultural heritage refers to those items (such as, but not only, monuments) of outstanding universal value,$^{63}$ whose deterioration impoverishes the heritage of all nations of the world. ${ }^{64}$ Intangible cultural heritage has recently been recognized ${ }^{65}$ and consists in the practices, representations, knowledge and skills recognized as part of cultural heritage by a community. ${ }^{66}$

Cultural rights are mentioned in different instruments. Article 27 of the Universal Declaration of Human Rights (UDHR) enshrines the right of everyone to "participate in the cultural life of the community". ${ }^{67}$ The Preamble of the International Covenant on Economic, Social and Cultural

62 Hurst Hannum, "The UDHR in National and International Law," Health and Human Rights 3, no. 2 (1998): 144-158, https://doi.org/10.2307/4065305.

63 Art. 1, "Convention Concerning the Protection of the World Cultural and Natural Heritage", opened for signature November 16, 1972, United Nations Treaty Series no. 1037, p. 151, https://treaties.un.org/doc/Publication/UNTS/ Volume\%201037/volume-1037-I-15511-English.pdf.

64 Preamble, "Convention Concerning the Protection of the World Cultural and Natural Heritage", signed on November 16, 1972, United Nations Treaty Series no. 1037, p. 151, https://treaties.un.org/doc/Publication/UNTS/ Volume\%201037/volume-1037-I-15511-English.pdf.

65 The chronological distance between the global recognition of tangible and intangible cultural heritage is evidenced, first, by the gap of several decades between the two conventions protecting them. The former, in fact, is enshrined in the UNESCO Convention Concerning the Protection of the World Cultural and Natural Heritage of 1972, whereas the latter is recognized in the UNESCO "Convention for the Safeguarding of the Intangible Cultural Heritage" of 2003.

66 Art. 1, "Convention for the Safeguarding of the Intangible Cultural Heritage," opened for signature October 17, 2003, United Nations Treaty Series no. 2368, 3, https://treaties.un.org/doc/Publication/UNTS/Volume\%202368/ v2368.pdf.

${ }_{67}$ Art. 27.1, United Nations, Charter of the United Nations, signed on 24 October 1945. 
Rights (hereinafter, ICESCR) recognizes that freedom of human beings can be achieved only if everyone can enjoy economic, social and cultural rights (emphasis added) ${ }^{68}$ Article 15 of the same Covenant recognizes the right of everyone to "take part in cultural life" 69 and the necessity of "the conservation, the development and the diffusion of science and culture"7o in order to "achieve the full realization of this right".71 More recently, General Comment No. 21 (2009) of the Committee on Economic, Social and Cultural Rights has underlined how the right of everyone to participate in cultural life is the basis for the enjoyment of the other cultural rights of the ICESCR. The same general comment mentions that, in order to ensure the right to take part in cultural life, the access to cultural goods and their preservation are required. Cultural life has been defined in the same document as a "broad, inclusive concept encompassing all manifestations of human existence", characterized by a dynamic nature as it is a "living process (...) with a past, a present and a future", created by the interactions of individuals and communities. ${ }^{72}$ In the General Comment, a definition of "to take part" has been provided as well. This right is divided into three main components: participation in, access to and contribution to cultural life. In particular, "access to" is defined as "the particular right of everyone (...) to know and understand his or her own culture and that of others through education and information (...) and to benefit from the cultural heritage and the creation of other individuals and communities".73

68 Preamble, "International Covenant on Economic, Social and Cultural Rights," opened for signature December 16, 1966, United Nations Treaty Series no. 993, 3, https://treaties.un.org/doc/Publication/UNTS/Volume\%20993/ volume-993-I-14531-English.pdf.

69 Art. 15.1.a, "International Covenant on Economic, Social and Cultural Rights," opened for signature December 16, 1966, United Nations Treaty Series no. 993, 3, https://treaties.un.org/doc/Publication/UNTS/Volume\%20993/ volume-993-I-14531-English.pdf.

70 Art. 15.2., "International Covenant on Economic, Social and Cultural Rights," opened for signature December 16, 1966, United Nations Treaty Series no. 993, 3, https://treaties.un.org/doc/Publication/UNTS/Volume\%20993/ volume-993-I-14531-English.pdf.

71 Art. 15.2., "International Covenant on Economic, Social and Cultural Rights," opened for signature December 16, 1966, United Nations Treaty Series no. 993, 3, https://treaties.un.org/doc/Publication/UNTS/Volume\%20993/ volume-993-I-14531-English.pdf.

72 Committee on Economic, Social and Cultural Rights, "General Comment No. 21 Right of Everyone to Take Part in Cultural Life (Art. 15, Para. 1 (a), of the International Covenant on Economic, Social and Cultural Rights)" (United Nations Economic and Social Council, December 21, 2009).

73 Committee on Economic, Social and Cultural Rights. 
Thus, the preservation of both tangible and intangible cultural heritage appears necessary to guarantee the respect of cultural rights, as the possibility to enjoy and participate in cultural life, its availability and accessibility, which are vital components of cultural rights, can be severely impaired by the destruction of cultural heritage, both tangible and intangible. Intangible cultural heritage has a constantly changing nature, as it is actively transformed by people who enjoy it, inheriting it from ancestors and transmitting it to future generations; the destruction of intangible cultural heritage, therefore, constitutes a serious threat to the enjoyment and participation in cultural life, protected by cultural heritage. Tangible cultural heritage is strictly linked to cultural rights as well. In fact, preservation of cultural items allows participation in cultural life, which is part of cultural rights; the relationship between the enjoyment of these rights and cultural heritage has already been recognized in internationally adopted instruments, such as in the already mentioned Article 15.2 of the ICESCR. Moreover, cultural heritage - both tangible and intangible - has a symbolic nature. Its protection positively influences cultural diversity and cultural identity, guaranteed as cultural rights.

The protection of cultural heritage, therefore, is necessary to ensure the enjoyment of cultural rights, since the possibility to benefit from intangible and tangible cultural heritage integrates the right to participate in cultural life and to benefit from culture and arts. On the other hand, its destruction can be considered an indirect violation of cultural rights.

\subsection{The Italian Experience in Constitutional Protection of Cultural} Heritage and Cultural Rights in Non-Conflictual Contexts

The strict link between cultural heritage, human rights and individual and collective conscienceof a nation has been reaffirmed also outside of conflictual situations. In this sense, it is useful to recall the protection of cultural heritage guaranteed, in Italy, at the constitutional level. Indeed, Article 9 of the Italian Constitution not only promotes culture and scientific and technological research, but also "safeguards natural landscape and the 
historical and artistic heritage of the Nation".74 This provision is one of the fundamental principles of the Constitution, thus is considered central in the Italian legal system. In fact, it has been recognized that being heirs of a vast cultural heritage is an integral part of the collective national conscience (and, in fact, the article refers to the heritage of the "Nation"). As the former president of the Italian Republic, Ciampi, said,

"It is in our artistic heritage, in our language, in the Italian creativity that the heart of our identity resides [...]. The 'Italy' inside each one of us is expressed in the humanistic culture, figurative art, music, architecture, poetry and literature of a single people."75

The primary role of the protection of cultural heritage has been affirmed also by the Italian Constitutional Court. In sentence 151/86 of 1986, the Court explicitly declared the primacy of the aesthetic-cultural value, which cannot be subordinate to any other since, due to Article 9 of the Constitution, it acquires a primary role. Thus, economic reasons cannot prevail, but rather the aim of protecting the cultural heritage should be the basis of decisions of an economic nature. ${ }^{7}$

The protection of cultural heritage is disciplined also in another article of the Italian Constitution, in particular in Article 117. The latter, reformed in 2001, establishes the distribution of competences between the State and the Regions and, in particular, declares that "the State has exclusive legislative powers in [...] protection of [...] cultural heritage", whereas "concurring legislation applies to [...] enhancement of cultural and environmental properties, including the promotion and organization of cultural activities".77 The discipline is complemented by the Code of Cultural

74 Art. 9, "Constitution of the Italian Republic", 1948. Discussing the protection of cultural heritage in case of armed conflicts, it has to be recalled that the Italian Constitution was drafted in the immediate aftermath of World War II. Even in a post-war scenario, the Constituent Assembly thought it was necessary to enshrine the protection of landscape and cultural heritage, elements facilitating the unification of the Italian people (it should be remembered that Italy was unified less than a century earlier).

75 Carlo Azeglio Ciampi, Intervento del Presidente della Repubblica Carlo Azeglio Ciampi in occasione della consegna delle medaglie d'oro ai benemeriti della cultura e dell'arte [Speech of the President of the Italian Republic Carlo Azeglio Ciampi on the delivery of the Gold Medals for Culture and Arts merit], May 5, 2003.

76 Corte Costituzionale Italiana [Italian Constitutional Court], Sent. 151/86 A. Giudizio di legittimità costituzionale in via principale [Judgment on question of constitutionality], No. 151/1986 (June 27, 1986).

77 Art. 117, "Constitution of the Italian Republic", 1948. 
Heritage and Landscape, which provides a more specific regulation of the subject. However, the shared competence between the State and the Regions has raised doubts regarding the distribution of competences. Addressing the issue, the Constitutional Court reiterated the unifying value of cultural heritage. In particular, the Court compared the protection of cultural heritage with the protection of the environment, as both are regulated by the Article 117.3(s) of the Italian Constitution. In this sense, it stated that like the protection of the environment, the protection of cultural heritage is a task, and in its exercise the State has the power to establish uniform standards of protection, valid in all the Regions and "non-derogable".78

Also, in its sentence 194/2013, the Court referred to Article 1.2 of the Code of Cultural Heritage and Landscape, which declares that "the protection and enhancement of cultural heritage contributes to the preservation of the collective national memory and its territory and to promote the development of culture" ${ }^{79}$ For the Court, this article implies that, on one hand, cultural heritage is an intrinsically common heritage, thus it cannot be arbitrarily divided; and, on the other hand, that it is by nature varied and mutable. ${ }^{80}$ In conclusion, the Court declared that to identify, conserve and protect cultural heritage it is necessary for these actions to be unitarily exercised. Hence, this competence has to be given to the State, whereas the Regions have competence in disciplining the enhancement and fruition of cultural heritage. ${ }^{81}$ Therefore, even though protection and valorization are connected issues, the former is given to the State, in order to provide the most adequate procedures to protect cultural heritage and a protection policy that considers Italian cultural heritage's role in unifying the Italian people.

\footnotetext{
78 Corte Costituzionale Italiana [Italian Constitutional Court], Sent. 232/2005. Giudizio di legittimità costituzionale in via principale [Judgment on question of constitutionality], No. 232/2005 (June 16, 2005).

79 Italian Republic, Article 1.2, D. Lgs. 42/2004. Cultural Heritage and Landscape Code (Codice dei beni culturali e del paesaggio), Article 1.2, Legislative Decree No 42 of 2004 on Official Gazette of the Italian Republic No 45 of 2004, translated by the Author.

8o Corte Costituzionale Italiana [Italian Constitutional Court], Sent. 194/2013 Giudizio di legittimità costituzionale in via principale [Judgment on question of constitutionality] (July 17, 2013).

81 Corte Costituzionale Italiana.
} 
In the complex issue of the distribution of competences within the Italian legal system, the individuation of cultural heritage items and their protection is left primarily to the State, whereas specific and detailed regulations are given to Regions. Hence, the discipline implements Article 9 of the Constitution, taking also into consideration how an adequate protection of cultural heritage allows not only the enjoyment of cultural rights, but also the complete development of a collective national identity.

\subsection{The Destruction of Cultural Heritage as an Attack on Human Rights and Human Dignity}

The destruction of cultural heritage undermines the possibility to effectively enjoy cultural rights, in particular the right to participate in cultural life and to enjoy culture. The undermining of these rights should not be underestimated. Even though cultural rights, together with economic and social rights, have long been considered as less necessary than civil and political rights, ${ }^{82}$ it has been recognized that they are all components of the wider category of "human rights". Moreover, it has been affirmed that, even though this category can be divided into different subcategories, is cohesive and homogeneous. Cultural rights, therefore, are not independent from neither economic and social rights, nor from civil and political ones and vice versa. ${ }^{83}$ Economic, social cultural rights were already included in the UDHR. Also, the absence of a hierarchy among the different categories of human rights was declared in 1993, in the Vienna Declaration and Programme of Action of the World Conference on Human Rights, which states that "all human rights are universal, indivisible, and interdependent and interrelated" 84 and - more explicitly - that "the international community

82 This is due also to the attitude towards them of some governments, which has so been described: "certain governments' challenges to economic and social rights, as well as some countries' ambivalence towards them". Henry J. Steiner, Philip Alston, and Ryan Goodman, International Human Rights in Context (Oxford: Oxford University Press, 2000).

83 See Office of the United Nations High Commissioner for Human Rights, Fact Sheet No. 33, Geneva, 2008, https:// www.ohchr.org/Documents/Publications/FactSheet33en.pdf.

84 World Conference on Human Rights, "Vienna Declaration and Programme of Action," adopted June 25, 1993, https://www.ohchr.org/Documents/Professionallnterest/vienna.pdf. The relation between the destruction of cultural heritage and the undermining of human rights is clearly stated in several reports of the Special Rapporteurs in the field of Cultural Rights and in the field of Human Rights, as well as in Resolutions of the Human Rights Council. The latter has repeatedly affirmed the position that "cultural rights are an integral part of human rights, 
must treat human rights globally in a fair and equal manner, on the same footing, and with the same emphasis". ${ }^{85}$ This declaration is not surprising, since cultural rights (including the enjoyment and participation to cultural life, which is effective only allowing the enjoyment of cultural heritage) have significant effects on different human rights, such as the freedom of expression, thought, opinion and religion. ${ }^{86}$

Second, it has been emphasized how the destruction of cultural heritage serves the purpose of facilitating the consolidation of "monolithic world views" and the "enmity toward 'the other', threatening the principle of equality, which is at the base of the enjoyment of all the human rights. In fact, artistic freedom - which results in the protection of cultural heritage from destruction - includes "the right to freedom of opinion, and freedom of thought, conscience and religion, as art is also a means of expressing a belief". ${ }^{87}$ Thus, "the implementation of human rights must take into consideration respect for cultural rights" ${ }^{88}$ In fact, the latter "are a key to the overall implementation of universal human rights", ${ }^{89}$ as they provide "important opportunities for the realization of other human rights", ${ }^{\circ}$ in particular of "the rights to freedom of opinion and expression, freedom of thought, conscience and religion, as well as the economic rights of the people who earn a living through tourism related to such heritage, the right to education and the right to development". ${ }^{11}$ The relation between cultural

which are universal, indivisible, interrelated and interdependent"; United Nations Human Rights Council, $25^{\text {th }}$ session, "Promotion of the enjoyment of the cultural rights of everyone and respect for cultural diversity" (UN Doc, April 15, 2004), U.N. Doc. A/HRC/RES/25/19, https://documents-dds-ny.un.org/doc/UNDOC/GEN/G14/136/10/ PDF/G1413610.pdf?OpenElement.

85 World Conference on Human Rights, "Vienna Declaration and Programme of Action", adopted June 25, 1993, https://www.ohchr.org/Documents/Professionallnterest/vienna.pdf.

86 Freedoms enshrined in the articles 18 and 19 of the International Covenant on Economic, Social and Cultural Rights.

${ }^{87}$ Human Rights Council, $34^{\text {th }}$ session, "Report of the Special Rapporteur in the field of cultural rights," January 16, 2017, U.N. Doc. A/HRC/34/56, https://undocs.org/en/A/HRC/34/56.

88 Par. 46, Human Rights Council, $34^{\text {th }}$ session, "Report of the Special Rapporteur in the field of cultural rights," January 16, 2017, U.N. Doc. A/HRC/34/56, https://undocs.org/en/A/HRC/34/56.

89 Par. 5, Human Rights Council, $31^{\text {st }}$ session, "Report of the Special Rapporteur in the field of cultural rights," February 3, 2016, U.N. Doc. A/HRC/31/59, https://undocs.org/A/HRC/31/59.

9o Par. 5, Human Rights Council, 31 $1^{\text {st }}$ session, "Report of the Special Rapporteur in the field of cultural rights," February 3, 2016, U.N. Doc. A/HRC/31/59, https://undocs.org/A/HRC/31/59.

91 Par. 51, Human Rights Council, 31 $1^{\text {st }}$ session, "Report of the Special Rapporteur in the field of cultural rights," February 3, 2016, U.N. Doc. A/HRC/31/59, https://undocs.org/A/HRC/31/59. 
heritage and rights internationally recognized - not only cultural, but also economic, social, civil and political - has been stated and confirmed. Therefore, cultural heritage must be protected not only for its intrinsic historical and artistic value, but also for its "crucial value for human beings in relation to their cultural identity"..$^{2}$

The importance of cultural heritage goes beyond the rights so far listed; in fact, it has been declared that the role of cultural heritage as a resource of cultural identity is so relevant that its intentional destruction "may have adverse consequences on human dignity and human rights". ${ }^{3}$ Cultural heritage is, in fact, a key component of the personal development of individuals. Without the possibility to experience cultural heritage, both tangible and intangible, the possibility for people to fully develop, both as individuals and as part of communities (from the local level, to the global one), is impaired. This possibility of full development, therefore, is undermined by the destruction of cultural heritage. ${ }^{94}$ The connection between cultural rights, development of personality and human dignity is enshrined also in the UDHR; its Article 22, in fact, states that "everyone, as a member of society, has the right to (...) cultural rights indispensable for his dignity and the free development of his personality". ${ }^{95}$ As cultural rights cannot be fully enjoyed without the possibility to have access to cultural heritage, the connection between the protection of cultural heritage and the respect of human dignity emerges as functional but evident.

Cultural heritage has to be considered a necessary element for the realization of several human rights and human dignity; thus, cultural heritage must be respected as part of a wider obligation to respect human rights.

92 Par. 53, Human Rights Council, 31 ${ }^{\text {st }}$ session, "Report of the Special Rapporteur in the field of cultural rights," February 3, 2016, U.N. Doc. A/HRC/31/59, https://undocs.org/A/HRC/31/59.

93 UNESCO, "Declaration concerning the Intentional Destruction of Cultural Heritage", September 29, 2003, Records of the General Conference, $32^{\text {nd }}$ session no. 1, 187, https://unesdoc.unesco.org/ark:/48223/pfoooo133171.page=68.

94 See Preamble, "Charter of the United Nations."

95 Art. 22, "Charter of the United Nations." 


\subsection{Returning to Human Rights to Enhance the Protection of Cultural Heritage}

As exposed above, the protection of cultural heritage is linked to the safeguard of several human rights. As a result, its protection from destruction due to cultural cleansing and from looting and smuggling to finance illicit activities is a key component in the effective enjoyment of several human rights. It is possible, therefore, to integrate IHL with IHRL in order to protect cultural heritage more effectively.

The necessity to protect cultural heritage and cultural rights in events of conflict has lately been proven by the conviction for war crimes of Ahmad Al Faqi Al Mahdi, guilty of having destroyed, in 2012, monuments and buildings - not military objectives - in Timbuktu, some of which were listed in the UNESCO World Heritage List. ${ }^{96}$ Even though this case dealt with individual international criminal responsibility, this conviction shows a trend in the public conscience. Having started with the attacks on cultural heritage during the conflict in the former Yugoslavia, ${ }^{97}$ it is still developing towards considering the deliberate destruction of cultural heritage as a serious breach of IHL rules. In fact, even though crimes against property (as the crimes committed by Al Mahdi) are considered as usually less grave than the ones against persons, the symbolic nature and importance for Malian culture of the sites destroyed make the attacks committed by Al Mahdi of particular gravity and importance..$^{8}$

Nonetheless, the IHL does not appear to be sufficient to bind ANSGs to respect cultural heritage. The integration of the rules of IHL with the

\footnotetext{
96 International Criminal Court Trial Chamber, Prosecutor v. Ahmad Al Faqi Al Mahdi Case No. ICC-01/12-01/15 (International Criminal Court 2016).

97 UNSC, "Final report of the United Nations Commission of Experts established pursuant to security council resolution 780 (1992). Annex XI: destruction of cultural property report", U.N. Doc. S/1994/674/ Add.2 (December 28, 1994).

$9^{8}$ As the summary of the judgement, released by the International Criminal Court, states, "the fact that the targeted buildings were not only religious buildings but had also a symbolic and emotional value for the inhabitants of Timbuktu is relevant in assessing the gravity of the crime committed". International Criminal Court, "Summary of the Judgment and Sentence in the Case of The Prosecutor v. Ahmad Al Faqi Al Mahdi," 2016.
} 
rules of IHRL would provide a stronger protection for cultural heritage. It is widely recognized that IHRL has to be applied at all times, ${ }^{99}$ even in case of conflicts, as they are inherent rights of all human beings. In fact, it has been pointed out that human rights are "an intrinsic part of the legal rules governing wars and other emergency situations". ${ }^{100}$ Regarding the obligation to respect human rights also in the event of armed conflicts, already 20 years ago the Institute of International Law noted that "in the last fifty years, the principles of the United Nations Charter and of human rights law have had a substantial impact on the development and application of international humanitarian law" ${ }^{101}$ More recently, the Human Rights Council has acknowledged that "human rights law and international humanitarian law are complementary and mutually reinforcing". ${ }^{102}$

Starting from the UDHR in 1948, human rights have progressively become precepts for States, which must act in conformity to them and protect them. Human rights are guaranteed not only in international matters (regarding the relations between States), but also in internal ones. ${ }^{103}$ The worldwide recognition of IHRL in its essential aspects could constitute valid help in the protection of cultural heritage. In particular, the link between the protection of cultural heritage and the obligation to guarantee the effective enjoyment of human rights should be remembered by States when adopting the measures addressed to them by the Security Council through the Resolution.

99 See, e.g., the International Court of Justice "Advisory Opinion on Legality of the threat or use of nuclear weapons" (International Court of Justice Reports, 1996), 226.

100 Hans-Joachim Heintze, "On the Relationship between Human Rights Law Protection and International Humanitarian Law," Int'l Rev. Red Cross 86 (2004): 789-814, https://doi.org/10.1017/S156077550018040X.

101 Institut de Droit International, "The Application of International Humanitarian Law and Fundamental Human Rights," Armed Conflicts in which Non-State Entities are Parties, 1999.

102 HRC Res. 9/9, U.N. Doc. A/HRC/RES/9/9 (September 18, 2008).

103 Francesco Francioni, "Beyond State Sovereignty: The Protection of Cultural Heritage as a Shared Interest of Humanity," Michigan Journal of International Law 25, no. 4 (2004): 1209-28. 


\section{CONCLUSION}

The majority of ongoing armed conflicts are of non-international nature. Thus, they include at least one ANSG. However, attempts to bind ANSGs to respect cultural heritage have proven unfruitful. Cultural heritage items are still illegally sold to finance ANSGs' activities activities and destroyed for strategic reasons. On a legal level, the main reason for this limitation is that the majority of ANSGs are not considered full subjects of international law. On a practical level, normally ANSGs do not want to comply to obligations in whose formation they did not participate. Consequently, international conventional instruments are not effective in filling the gap left by the non-recognition of the subjectivity and accountability of ANSGs.

Resolution 2347 (2017) has been received as a step forward in the protection of cultural heritage in case of armed conflicts. Certainly, it aims at strengthening the international cooperation among States, international organizations, agencies and other stakeholders, in order to enhance the protection of cultural heritage against the threats of terrorist groups in armed conflicts. Considering the difficulties in binding ANSGs to respect cultural heritage during armed conflicts, international synergies among States and different stakeholders become fundamental. However, a thorough analysis conducted applying the means of interpretation of UN Security Council resolutions leads to the conclusion that Resolution 2347 lacks sufficient clarity, is too focused on the fight against terrorism and, ultimately, does not clearly bind States. Today, the latter often invoke the principle of state sovereignty, claiming that they will protect the cultural items they feel as their own national emblems, thus impairing the effective implementation of rules protecting cultural rights, particularly when treaties do not establish effective monitoring mechanisms. Despite these shortcomings and the difficulties in providing a legally and theoretically solid reasoning for binding ANSGs to the respect of international rules and overcoming the claims of national sovereignty, the international cooperation and the involvement of different actors included in the Resolution 
have to be welcomed and put into practice. This necessity is based not only on the obligations of IHL, but also IHRL. In fact, besides illicitly financing the activities of ANSGs, the destruction and looting of cultural heritage impair the effective enjoyment of different human rights wherever they occur and, ultimately, undermine the human rights of all mankind.

\section{BIBLIOGRAPHY}

Amoroso, Alessandro Mario et al. "The War Report: Armed Conflicts in 2018." A Paper, Geneva Academy of International Humanitarian Law and Human Rights, 2019.

Bellal, Annyssa. "What Are 'Armed Non-State Actors'? A Legal and Semantic Approach." In International Humanitarian Law and Non-State Actors, edited by Ezequiel Heffes, Marcos D. Kotlik, and Manuel J. Ventura, 21-46. The Hague: T.M.C. Asser Press, 2020. https://doi.org/10.1007/978-94-6265-3399_2.

Busé, Margaret S. "Non-State Actors and Their Significance." Journal of Conventional Weapons Destruction 5, no. 3 (2001).

"Charter of the United Nations". Opened for signature June 26, 1945. https:// treaties.un.org/doc/Publication/UNTS/No\%2oVolume/Part/un_charter.pdf.

Ciampi, Carlo Azeglio. Intervento del Presidente della Repubblica Carlo Azeglio Ciampi in occasione della consegna delle medaglie d'oro ai benemeriti della cultura e dell'arte [Speech of the President of the Italian Republic Carlo Azeglio Ciampi for the delivery of the Gold Medals for Culture and Arts merits], May 5, 2003.

Committee on Economic, Social and Cultural Rights. "General Comment No. 21 Right of Everyone to Take Part in Cultural Life (Art. 15, Para. 1 (a), of the International Covenant on Economic, Social and Cultural Rights)." United Nations Economic and Social Council, December 21, 2009. 
Constantinides, Aristotle. "Human Rights Obligations and Accountability of Armed Opposition Groups: The Practice of the Un Security Council." Human Rights E International Legal Discourse 4, no. 1 (2010).

"Convention for the Protection of Cultural Property in the Event of Armed Conflict." Opened for signature May 14, 1954. United Nations Treaty Series no. 249, 215, https://treaties.un.org/Pages/showDetails. aspx?objid=0800000280145bac.

"Convention (I) for the Amelioration of the Condition of the Wounded and Sick in Armed Forces in the Field, Geneva, 12 August 1949, Commentary of 2016. Article 3: Conflicts not of an international character. Accessed August 22, 2020. https://ihl-databases.icrc.org/applic/ihl/ihl.nsf/Comment.xsp?acti on=openDocument\&documentId=59F6CDFA490736 $1 \mathrm{C}_{1257} \mathrm{~F}_{7}$ Doo4BAoEC .

Corte Costituzionale Italiana [Italian Constitutional Court]. Sent. 151/86 A. Giudizio di legittimità costituzionale in via principale [Judgment on question of constitutionality], No. 151/1986 (June 27, 1986).

Corte Costituzionale Italiana [Italian Constitutional Court]. Sent. 194/2013 Giudizio di legittimità costituzionale in via principale [Judgment on question of constitutionality] No. 194/2013 (July 17, 2013).

Corte Costituzionale Italiana [Italian Constitutional Court]. Sent. 232/2005. Giudizio di legittimità costituzionale in via principale [Judgment on question of constitutionality], No. 232/2005 (June 16, 2005).

Evans, Graham, and Jeffrey Newnham. The Penguin Dictionary of International Relations. New York: Penguin Group USA, 1998.

Fleck, Dieter. The Handbook of International Humanitarian Law. Oxford and New York: Oxford University Press, 2013.

Fortin, Katharine. "The Law on Belligerency and Insurgency, and International Legal Personality." In The Accountability of Armed Groups under Human Rights Law, edited by Katharine Fortin. Oxford: Oxford University Press, 
2017. Accessed September 21, 2020. https://oxford.universitypressscholarship. com/view/10.1093/oso/9780198808381.001.0001/oso-9780198808381-chapter-4.

Francioni, Francesco. "Beyond State Sovereignty: The Protection of Cultural Heritage as a Shared Interest of Humanity." Michigan Journal of International Law 25, no. 4 (2004).

Gaub, Florence. "State Vacuums and Non-State Actors in the Middle East and North Africa." In The Frailty of Authority Borders, Non-State Actors and Power Vacuums in a Changing Middle East, edited by Lorenzo Kamel. Roma: Edizioni Nuova cultura, 2017.

"Geneva Convention for the Amelioration of the Condition of the Wounded and Sick in Armed Forces in the Field." Opened for signature August 12, 1949. United Nations Treaty Series no. 75. https://ihl-databases.icrc.org/applic/ihl/ihl. nsf/7c4do8d9b287a42141256739003e636b/fe2oc3d903се27е3c125641eo04a92f3

Gerstenblith, Patty. "Beyond the 1954 Hague Convention.” In Cultural Awareness in the Military: Developments and Implications for Future Humanitarian Cooperation, edited by Robert Albro and Bill Ivey, 83-99. Springer, 2014.

Hall, Macer. "Boris Johnson Urges Brits to Vote Brexit to 'Take Back Control'." Daily Express, June 20, 2016. https://www.express.co.uk/news/politics/681706/ Boris-Johnson-vote-Brexit-take-back-control.

Hannum, Hurst. "The UDHR in National and International Law." Health and Human Rights 3, no. 2 (1998). https://doi.org/10.2307/4065305.

Hausler, Kristin. "Cultural Heritage and the Security Council: Why Resolution 2347 Matters.” QIL-Question of International Law. QIL, Zoom-In 48 (2018). Heintze, Hans-Joachim. "On the Relationship between Human Rights Law Protection and International Humanitarian Law." International Review Red Cross 86 (2004). https://doi.org/10.1017/S156077550018040X.

Henckaerts, Jean-Marie. "The Protection of Cultural Property in Non-International Armed Conflicts." In Protecting Cultural Property in Armed Conflict, edited 
by Nout van Woudenberg and Liesbeth Lijnzaad. International Humanitarian Law Series, v. 29. Leiden; Boston: Martinus Nijhoff Publishers, 2010.

Institut de Droit International. "The Application of International Humanitarian Law and Fundamental Human Rights, in Armed Conflicts in which NonState Entities are Parties." The Institute of International Law, 1999.

International Committee of the Red Cross. "Geneva Conventions on the Law of War," August 12, 1949. 75 No. 973. United Nations Treaty Series.

International Committee of the Red Cross. "Rule 38. Attacks Against Cultural Property." IHL Database. Customary IHL (blog). Accessed October 23, 2020. https://ihl-databases.icrc.org/customary-ihl/eng/docs/v1_rul_rulez8.

"International Covenant on Economic, Social and Cultural Rights." Opened for signature December 16, 1966. United Nations Treaty Series no. 993, 3. https://treaties.un.org/doc/Publication/UNTS/Volume\%20993/volume-993I-14531-English.pdf.

International Court of Justice. "Advisory Opinion on Legality of the threat or use of nuclear weapons." International Court of Justice Reports, 1996, 226. International Criminal Court. "Summary of the Judgment and Sentence in the Case of The Prosecutor v. Ahmad Al Faqi Al Mahdi," 2016.

International Criminal Court Trial Chamber, Prosecutor v. Ahmad Al Faqi Al Mahdi Case No. ICC-01/12-01/15 (International Criminal Court 2016).

International Law Association. "Johannesburg Conference on Non State Actors." International Law Association Reports of Conferences, 2016.

INTERPOL. "Protecting Cultural Heritage through Interagency Cooperation. WIESBADEN, Germany - International Experts on the Illicit Trade of Cultural Property Have Met to Boost Interagency Cooperation Both at the National and International Level." September 23, 2019. https://www.interpol. int/News-and-Events/News/2019/Protecting-cultural-heritage-throughinteragency-cooperation. 
INTERPOL. "The Issues - Cultural Property." Accessed October 20, 2020. https://www.interpol.int/Crimes/Cultural-heritage-crime/The-issues-culturalproperty.

Jackson, Ashley. "In Their Words: Perceptions of Armed Non-State Actors on Humanitarian Action." Geneva: Geneva Call, May 2016. https:// www.genevacall.org/wp-content/uploads/dlm_uploads/2016/og/WHS_ Report_2016_web.pdf.

Jakubowski, Andrzej. "Resolution 2347: Mainstreaming the Protection of Cultural Heritage at the Global Level." Questions of International Law 48 (2018).

Legal Consequences for States of the Continued Presence of South Africa in Namibia (South West Africa) notwithstanding Security Council Resolution 276 (1970), Advisory Opinion (International Court of Justice June 21, 1971). McQuinn, Brian, and Fabio Oliva. "Preliminary Scoping Report - Analyzing and Engaging Non-State Armed Groups in the Field." United Nations System Staff College, n.d.

Ocampo, Satur. "Duterte's Odd Defense of Philippine Sovereignty." Bulatlat, April 22, 2018. https://www.bulatlat.com/2018/04/22/dutertes-odd-defensephilippine-sovereignty.

Office of the United Nations High Commissioner for Human Rights. "Fact Sheet No. 33." Geneva, 2008. https://www.ohchr.org/Documents/Publications/ FactSheet33en.pdf.

Papastavridis, Efthymios. "Interpretation of Security Council Resolutions under Chapter VII in the Aftermath of the Iraqi Crisis." International and Comparative Law Quarterly 56, no. 1 (January 2007): 83-118. https://doi. org/10.1093/iclq/lei151.

Pavia, Will. "Amazon Rainforest Belongs to Brasil Not Mankind, Bolsonaro Tells UN.” The Times, September 25, 2019. https://www.thetimes.co.uk/ article/amazon-rainforest-belongs-to-brazil-not-mankind-bolsonaro-tellsun-2j2f 55 l2j. 
Pearlman, Wendy, and Kathleen Gallagher Cunningham. "Non-state Actors, Fragmentation, and Conflict Processes." Journal of Conflict Resolution 56, no. 1 (February 2012). https://doi.org/10.1177/0022002711429669.

Posner, Eric A. "The International Protection of Cultural Property: Some Skeptical Observations." Chicago Journal of International Law 8, no. 1 (n.d.).

"Protocol Additional to the Geneva Conventions of 12 August 1949 and Relating to the Protection of Victims of Non-International Armed Conflicts (Protocol II)". Opened for signature June 8, 1977. United Nations Treaty Series, vol. 1125. https://treaties.un.org/doc/publication/unts/volume\%201125/volume1125-i-17513-english.pdf.

Republic of Italy. "Cultural Heritage and Landscape Code of the Italian Republic of January 22, 2004, D. Lgs. 42/2004”. https://www.camera.it/parlam/leggi/ deleghe/testi/o4042dl.htm.

"Rome Statute of the International Criminal Court." Opened for signature July 17, 1998. United Nations Treaty Series, vol. 2187, No. 38544.

Republic of Italy. "Constitution of the Republic of Italy - 1948." https://www. senato.it/documenti/repository/istituzione/costituzione.pdf.

Richardson, Paul B. "Sovereignty, the Hyperreal, and 'Taking Back Control." Annals of the American Association of Geographers 109, no. 6 (November 2, 2019). https://doi.org/10.1080/24694452.2019.1587283.

Schneckener, Ulrich. "Spoilers or Governance Actors?: Engaging Armed NonState Groups in Areas of Limited Statehood." SFB Governance working paper series, 21, 2009. https://www.sfb-governance.de/publikationen/sfb7oo-working_papers/wp21/index.html.

"Second Protocol the Hague Convention of 1954 for the Protection of Cultural Property in the Event of Armed Conflict." Opened for signature March 26, 1999. United Nations Treaty Series no. 2253, 172. https://treaties.un.org/ Pages/showDetails.aspx?objid=080oooo280o76dd2. 
Shultz, Richard H., Douglas Farah, and Itamara V. Lochard. "Armed Groups: A Tier-One Security Priority." INSS Occasional Paper. USAF Institute for National Security Studies, 2004.

Steiner, Henry J., Philip Alston, and Ryan Goodman. International Human Rights in Context. Oxford: Oxford University Press, 2000.

UNESCO. "Convention for the Safeguarding of the Intangible Cultural Heritage." Opened for signature October 17, 2003. United Nations Treaty Series no. 2368, 3. https://treaties.un.org/doc/Publication/UNTS/Volume\%202368/v2368.pdf. UNESCO. "Declaration concerning the Intentional Destruction of Cultural Heritage." September 29, 2003. Records of the General Conference, $32^{\text {nd }}$ session no. 1, 187, https://unesdoc.unesco.org/ark:/48223/pfoooo133171.page=68.

United Nations Human Rights Council, $25^{\text {th }}$ session. "Promotion of the enjoyment of the cultural rights of everyone and respect for cultural diversity." April 15, 2004, U.N. Doc. A/HRC/RES/25/19, https://documents-dds-ny.un.org/ doc/UNDOC/GEN/G14/136/10/PDF/G1413610.pdf?OpenElement.

United Nations Human Rights Council, 34 ${ }^{\text {th }}$ session. "Report of the Special Rapporteur in the field of cultural rights." January 16, 2017, U.N. Doc. A/ HRC/34/56, https://undocs.org/en/A/HRC/34/56.

United Nations Human Rights Council, 9th session. Res. 9/9, "Protection of the human rights of civilians in armed conflict." September 18, 2008. U.N. Doc. A/HRC/RES/9/9.

United Nations Security Council, "7907"th meeting,", S/PV.7907, March 24, 2017. https://www.securitycouncilreport.org/atf/cf/\%7B65BFCF9B-6D27-4E9C8CD3-CF6E4FF96FF9\%7D/s_pv_7907.pdf.

United Nations Security Council. "Final report of the United Nations Commission of Experts established pursuant to security council resolution 780 (1992). Annex XI: destruction of cultural property report.” U.N. Doc. S/1994/674/ Add.2 (December 28, 1994). 
United Nations Security Council. Res 2331, U.N. Doc. S/RES/2331 (December 20, 2016).

United Nations Security Council. Res 2340, U.N. Doc. S/RES/2340 (February $8,2017)$.

United Nations Security Council. Res 2349, U.N. Doc. S/RES/2349 (March 31, 2017).

United Nations Security Council. Res. 2347, U.N. Doc. S/RES/2347 (March 24, 2017).

"Vienna Convention on the Law of Treaties". Opened for signature May 23, 1969. United Nations Treaty Series no. 1155, https://treaties.un.org/doc/ Treaties/1980/o1/19800127\%2000-52\%20AM/Ch_XXIII_o1.pdf.

Wood, Michael C. "Interpretation of Security Council Resolutions." Max Planck Yearbook of United Nations Law 2 (1998).

World Conference on Human Rights. "Vienna Declaration and Programme of Action." June 25, 1993, https://www.ohchr.org/Documents/ ProfessionalInterest/vienna.pdf. 